\title{
Gastronomy, Gogol, and His Fiction
}

The mention of "gastronomy and Gogol" may immediately make us think of the good-natured pair in Old-Fashioned Landowners, who, if they were not eating, were sure to be sleeping. Or perhaps what comes to mind is that remarkable five-by-five figure of Peter Petrovich Petukh, whom Gogol appropriately described as a "round watermelon." And who can forget how Sobakevich ever so quietly and "innocently" alone dispatched that noble sturgeon at the breakfast party given by the chief of police, or how the thoroughly tipsy Khlestakov bragged about the "dream of a soup" that was delivered to him in St. Petersburg from no other gastronomic paradise than Paris itself. Nor can we forget Khlestakov's other soup-the one more like the River Nile (with feathers) - which was so ill-received and yet eaten with such alacrity by the starving braggart. Perhaps only Vladimir Nabokov did not laugh at Puzatyi Paciuk and his ingenious way of transporting varenyky to his mouth without moving an inch-and he first had to dip them into a dish of sour cream that was placed on a low barrel in front of him. ${ }^{1}$ And what about that pan of fried eggs that was rushed onto the stage in Meyerhold's production of Gogol's The Marriage, in which one of the suitors for the hand of the merchant's daughter-much to the confusion of the others-is called "Fried Eggs."

It would seem that no matter which of Gogol's literary works one considers-Evenings on a Farm Near Dikanka, short stories that make up the

1. Vladimir Nabokov, Nikolai Gogol (New York, 1961), pp. 31-32.

Varenyky (vareniki in Russian) is the favorite among a variety of dumplings (comparable to Italian ravioli) made of soft dough with a variable filling. In Ukrainian cookery curd filling is the national favorite. For definitions of Ukrainian and Russian dishes the following books, as well as standard reference tools, were consulted: Beryl Gould-Marks, Eating the Russian Way (London, 1963), 128 pp.; R. P. Kengis, Prigotovlenie muchnykh konditerskikh izdelii (Moscow, 1951), 248 pp.; Nikolai Markevich, Obychai, pover'ia, kukhnia $i$ napitki malorossiian (Kiev, 1860), 171 pp.; Marie Alexandre Markevitch, The Epicure in Imperial Russia (San Francisco, 1941), 103 pp.; Nina Nikolaevna Selivanova, Dining and Wining in Old Russia (New York, 1933), 154 pp.; Savella Stechishin, Traditional Ukrainian Cookery (Winnipeg, 1959), 497 pp.; A. N. Toliverova, Skoromnyi i postnyi domashnii stol, 3rd ed. (St. Petersburg, 1908), 518 pp.

In true Gogolian fashion, this theme was suggested to the author six years ago by Professor Anna Pirscenok of Lehigh University. I am further indebted to Professors Carrol F. Coates, John Walker, and Roger C. Norton for their valuable suggestions after the presentation of this paper in April 1968 at a Humanities Conference at Harpur College. 
Mirgorod collection, the Petersburg stories, Rome, the comedies The Inspector General and The Marriage, or Dead Souls-one finds everywhere not only heroes who like to eat well but unforgettable descriptions of mouth-watering appetizers, robust dinners, lusty banquets, savory suppers, breakfasts, midmorning and midnight snacks, and epicurean feasts fit for a king-"a necklace of dishes-caviar, cheeses, pickled mushrooms, openki [to a seasoned mushroom gourmet this is a delicacy], and new dispatches from the kitchen in covered dishes through which one could hear the sizzling of butter."2 And these dishes are only the $z a k u s k i-$ the Russian version of a Swedish smorgasbord. However, when they are expertly prepared, artistically decorated with greens, and aesthetically arranged on cut glass and silver dishes and placed on a separate table, so that one can fully appreciate the magnificence of their appetizing color combinations, they can be as exciting as any constellation of the Bolshoi Ballet. It is possible to eat oneself to a standstill even before soup is served, and that is only the beginning: the calf, milk-fed for two years, spit-roasted and stuffed with giblets and other incredibly rich and delectable morsels is yet to come!

A more serious consideration of these gastronomic descriptions reveals that gastronomy in Gogol's works is neither accidental nor an end in itself. Nor is it merely a manifestation of the author's personality. Nature blessed Gogol with a sweet tooth, a hearty appetite, and an uncommonly prodigious stomach. It is ironic that he died of acute malnutrition, which-though accelerated by the medical malpractice of his time-was mainly his own fault, for like his heroine Pulkheriia Ivanovna, he chose to starve himself to death. $\mathrm{He}$ suffered for years from gastric disorders and other symptoms, but as F. C. Driessen and others before him have pointed out, a purely physical explanation of Gogol's suffering is unsatisfactory. ${ }^{3}$ Doctors at home and abroad accused him of hypochondria, and the memoirs of his contemporaries and his own letters attest to a definite correlation between his frame of mind and his illnesses, real or imaginary. Here, however, we are concerned with Gogol's intestinal disorders, which I believe were not only psychosomatic but also brought on by his ambivalence toward food, which he associated with sex.

It is obvious in the author's biography that like the satirical portraits he painted in Dead Souls he manifested a passion for eating-a "zador," as he called it, "likho poobedat'." In the fourth chapter of Dead Souls Gogol made an open confession:

2. N. V. Gogol, Sobranie sochinenii, 6 vols. (Moscow, 1959), 5:315-16. Future references to Gogol's works, unless otherwise indicated, will be to this edition, cited henceforth simply by volume and page number. All references to deity will be capitalized, and all translations, except for the instances indicated, are my own.

3. F. C. Driessen, Gogol as a Short-Story Writer (The Hague, 1965). See especially the chapter entitled "Gogol and Anxiety," pp. 16-58. 
The author must confess that he is very envious of the appetite and the digestion of this sort of people [i.e., middling, average]. He dismisses as insignificant all those great gentlemen who live in Petersburg and Moscow and spend their time in deliberating what to eat tomorrow and what sort of dinner they are going to have the day after, and who toss a pill into their mouths before sitting down to dinner and swallow oysters, sea spiders, and other marvels, and then go for a cure to Carlsbad or the Caucasus. No, these gentlemen have never roused his envy. But gentlemen of the middling sort who ask for a ham at one post-station and a suckling pig at another, and a portion of sturgeon or some smoked sausage and onion at a third, and then sit down, as if nothing had happened, to a table at any time you please, and sterlet soup with pieces of burbot and soft roe hisses and gurgles between their teeth and is followed by a rasstegai or a kulebiaka with a fat catfish tail so that it makes other people's mouths water-these are the gentlemen who have been truly blessed by heaven !

$(5: 63-64)$

Gogol himself was known for his culinary artistry. Before leaving for St. Petersburg he wrote to his uncle, Peter Kosiarovsky: "I know some trades: I am a good tailor, I am not bad at painting frescoes on walls, I work in the kitchen and already know quite a bit about the art of cooking; if you think I am joking-ask mother." ${ }^{, 5}$ In St. Petersburg Gogol and his friends entertained each other at tea parties and dinners, and Gogol himself prepared many Ukrainian dishes. His interest in cooking was not evanescent, nor was his repertoire limited to Ukrainian specialties. When he returned from his first visit to Rome, he entertained friends at the Aksakovs by preparing huge quantities of quivering macaroni and cheese. There can be little doubt that these meticulously drawn bouts at the table and in the kitchen-described in such detail and with such infinite care and love-are a manifestation of Gogol's personality and a definite characteristic of his art. But Gogol did not simply endow his heroes with hearty appetites and sturdy, if somewhat "protruding," stomachs. In my opinion the author used gastronomy as a literary device. This overlooked detail helps to underscore the fact that Gogol worked con-

4. Rasstegai is raised pastry, rectangular in shape, filled either with a stuffing of fish or a mixture of meat and onions. The classic stuffing for rasstegai, just as for kulebiaka, has a base of visiga, the gelatinous marrow of the sturgeon's backbone (to a Russian, a delicacy). For everyday use, fatty rice, sliced eggs, and onions are added to the meat or fish. Kulebiaka is a large four-cornered fish and cabbage (or kasha and cabbage) pie of choux, puff, or short crust pastry, with a top crust and generally containing two or three different savory layers. The classic kulebiaka has at its base visiga; as a substitute for visiga finely shredded pancakes, cooked rice, kasha, or cabbage may be used to absorb some of the juices (the inside of a kulebiaka should be moist and "gooey") and to prevent the pastry from being soggy. One may substitute meat for fish or have a sweet filling.

5. Pis'ma N. V. Gogolia, ed. V. I. Shenroka, 4 vols. (St. Petersburg, 1901), 1: 107. 
sciously-as Dmitrij Tschižewskij has already shown-to a much greater extent than many had assumed. It is the task of this analysis to show where Gogol used gastronomy as a literary device and to what purpose.

In a manner characteristic of the entire volume of Gogol's Evenings, The Fair at Sorochintsy begins with a description of bountiful nature. There are "kitchen gardens topped by stately sunflowers" and "gray haystacks and golden sheaves of corn," and "the broad branches of cherry, plum, apple, and pear trees bend under their load of fruit" $(1: 14-15)$. These descriptions of the cornucopia of the Ukraine may at times precede the narrative, or may be given, as in May Night, in a few deft strokes during the course of the action. Ethnographic in character, such descriptions are absolutely essential to the stories, for they help us place the action, even though in their totality-that is, in combination with Gogol's flights of imagination-they create a Ukraine that is not the real Ukraine at all, but a land of fantasy. ${ }^{6}$ Yet Gogol does proceed from real details of Ukrainian folk life, and when he deals with food there is nothing fantastic about it-the Ukrainian and Russian national dishes described can be verified in any modern cookbook. As a matter of fact, when it comes to food Gogol seems to be devoid of imagination: his Tsarina, like her underlings, consumes halushky - except that hers, because of her position, are golden. Once in a while Gogol does lapse into hyperbole (Sobakevich's vatrushka becomes the size of a plate), but then everything in his house, in keeping with his character, is unduly large and crude.

The apple and cherry orchards, the stately sunflowers, the cucumber patches, and the mountains of sweet-smelling melons and honeydews that place the action of Gogol's stories in the garden of Russia, the breadbasket of Europe, are as necessary as olive groves, sycamores, and especially cicadas would be if the setting were to be Greece. But bountiful nature is not the only thing ethnographic in character. Gogol time and again introduces us to a variety of specifically Ukrainian dishes: first and foremost are halushky, pampushky, shyshky, putria, holubtsi, and korzhy. ${ }^{7}$ These traditional Ukrainian dishes-like the Ukrainisms (kavun, horilka, tsybulia, bublyk) that have their Russian equivalents-are mentioned to provide local color. So closely are

6. It is standard practice, while reiterating that Gogol's Ukraine is a figment of his imagination, to omit entirely accounts to the contrary. When I. S. Aksakov visited the Ukraine in 1848, he wrote: "Vezde zdes' tak i torchit Gogol' so svoimi 'Vecherami na khutoke bliz Dikan'ki.' Tol'ko tut vy pochuvstvuete vse dostoinstvo, vsiu vernost' etikh opisannii," cited in V. V. Zenkovsky, N. V. Gogol' (Paris, 1961), p. 64.

7. Halushky is the Ukrainian name for dumplings made of batter or a thick dough mixture and served as a side dish or an accompaniment to a roast; halushky may also replace croutons in soups. Pampushky (in Ukrainian cookery) are yeast-raised doughnuts, with or without a filling. Shyshky are small wedding cakes. Putria is a variety of kasha (see note 16 for a definition of kasha). Holubtsi are made of cabbage leaves stuffed with meat and rice. Korzhy are unleavened plain flat cakes made with lard. 
these dishes associated by Gogol with the Ukraine that they are confined to the short stories that appear in the two volumes of Evenings and to $V i i$ and Taras Bulba of the Mirgorod collection.

Gogol makes further use of gastronomy in Evenings to reveal Ukrainian social and religious customs as well as the psychology of his simple heroes. Describing the wedding in St. John's Eve, Gogol wrote: "Preparations for the wedding were made. They baked shyshky [wedding cakes], sewed towels and kerchiefs, and rolled out a barrel of vodka, sat the young couple down at the table, cut the korovai [the wedding loaf], struck the bandury ... and the merrymaking began" $(1: 52) .{ }^{8}$ A similar description of a wedding is found in The Horrible Vengeance, with the addition of yet another Ukrainian customthat of baking into the crust of the korovai some small coins for the musicians. In The Fair at Sorochintsy, however, Gogol marries off Paraska without the customary ritual. Perhaps the fast tempo of the story demands such a precipitate ending, or perhaps Gogol's sense of measure prevented him from injecting another gastronomic feat. He already had created a most successful comic scene between the gluttonous, amorous popovich and Khivria, in which the former has a rather difficult choice to make between a varenyk and the seemingly innocent termagant-turned-lamb, Khivria. Similarly, in Christmas Eve we learn that it is customary in the south of Russia to eat kutia on Holy Night and that one abstains from meat and dairy dishes then. This is revealed in Vakula's disbelief and horror at seeing Paciuk eat skoromnye varenyky -that is, varenyky filled with cheese and dipped generously in sour cream. ${ }^{9}$

In a typically Gogolian manner, while talking about one thing to reveal another (in this instance, a popular belief), Gogol says: "Indeed it is small wonder that he [the devil] should be cold, being used day after day to knocking about in hell, where, as we all know, it is not as cold as it is with us here in winter, and where, putting on his cap and standing before the hearth, like a real chef, he fries sinners with as much satisfaction as a peasant woman fries sausages on Christmas" $(1: 114)$. Thus Gogol reveals the custom of frying sausages to break the fast on Christmas. In Christmas Eve, following an ancient tradition, Gogol's Ukrainians go caroling late at night and receive for their singing of the koliadky a piece of kovbasa, varenyky, palianitsi, or pyrihy. ${ }^{10}$ By combining this custom with Solokha's hiding of her numerous

8. The bandura is a musical instrument similar to the guitar, but with twelve (or more) strings.

9. Kutia is a ritual dish and an integral part of the Holy Night supper. It consists of boiled wheat sweetened with honey and sprinkled with poppy seeds. Boiled rice may also be used for kutia, but then raisins and sometimes also nuts are added.

10. Kovbasa is sausage; palianitsi are small flat breads; pyrihy are large-sized yeastraised rolls, distinct from pyrozhky, which are smaller, daintier, oblong in shape, and 
sweethearts in empty coal sacks, Gogol cleverly creates a case of mistaken identity. When the sacks are discovered, everyone assumes that they contain all kinds of heavenly delicacies, and they fight among themselves for possession of the sacks. One can imagine the winner's surprise (and the smile of the reader, who has been in on the secret all along), when instead of a fat pig ready for the slaughter, out crawls none other than the village elder!

Gogol also makes use of gastronomy in Evenings to indicate what to the Cossacks was the height of well-being. In St. John's Eve the narrator makes the following wish for his grandfather: "May he rest in peace! May he have in the other world nothing but loaves of bread made of the finest wheat and poppy cakes with honey" $(1: 43)$. Apparently the Cossacks pictured heaven as an excellent hotel-restaurant-the kind that could proudly display Michelin's hard-to-earn stars. Vakula makes a similar remark in Christmas Eve when he comes to Paciuk for advice. And in The Lost Epistle the mentality of the simple Ukrainian is once more revealed in his assertion that he saw the Tsarina herself in a new gray svytka, wearing red boots, and, like any red-blooded Ukrainian, eating halushky, with the distinction that hers are golden. ${ }^{11}$ It is irrelevant whether or not the intrepid Cossack really did see the Tsarina. What is important is that when he did see her in his mind's eye, she was wearing what the Cossack would have liked to wear himself and she was eating one of the most beloved of all Ukrainian national dishes. The emphasis should be placed not on the halushky but on eating as a pleasurable pastime. In The Inspector General the mayor, visualizing himself in St. Petersburg at the moment of his ultimate glory, smacks his lips as he dreams of two fishes-riapushka (lake salmon) and koriushka (smelt)-which are for him the ultimate goal and pleasure in life.

In Evenings, food for the strong and dynamic Ukrainians is merely a means to an end and not an end in itself. Gogol's Ukrainians do not linger over the table. Their energies are engaged in fighting for the preservation of their Greek Orthodox faith and the independence of their homeland. In Taras Bulba the only account of food that is worth mentioning is at the beginning of the story, when Andrei and Ostap return home from the academy. Actually it amounts to a denial of all fine food, and any further mention of food is only cursory - bread and salo or korzhy and vodka. When we do find, however, in Evenings a lengthy description of gastronomy, it is in contrast to its function in Old-Fashioned Landowners, Ivan Fedorovich Shponka and His Aunt, and Dead Souls and is used mainly for comic effect. Who can forget the scene with the amorous and gluttonous popovich in The Fair at Sorochintsy? Or the gluttonous stranger in May Night who was invited to an evening repast

with tapering ends. Both pyrihy and pyrozhky may have a variety of savory or sweet fillings.

11. A soytka is a full coat, a kind of caftan. 
but in his greed choked on a halushka and hence was doomed forever to mount the chimney at dusk and haunt the little hut that had befriended him? Or the scene with Puzatyi Paciuk and his ingenious way of eating varenyky with sour cream, all without moving an inch?

"Let's see," he [Vakula] said to himself, "how Paciuk will eat varenyky. He certainly won't want to bend down to lap them up, the way he ate halushky. Besides he couldn't: he must first dip the varenyk into sour cream."

No sooner had he thought this, than Paciuk opened his mouth, looked at the varenyky, and opened his mouth still wider. At that moment a varenyk popped out of the bowl, splashed into the sour cream, turned over, lept upwards and flew straight into his mouth. Paciuk ate it, and opened his mouth again, and another varenyk went through the same performance. The only trouble that he took upon himself was to munch them and swallow them.

And what about the feast spread before the Zaporozhets in The Lost Epistle that never reached his mouth until he had the sense to bless the table the devils had set before him? In this particular instance Gogol makes gastronomy serve a triple purpose. The comic scene is once more built around the table, and what is on the table provides local color. However, by giving his devils all those same passions he gives his Cossacks, Gogol humanizes them-especially so, since they eat food fit for any Cossack's table: "Table pork, sausages, onion minced with cabbage, and many other dainties" (1:95). The table is as long as the road from "Konotop to Baturin" and the hero wields a fork the size of a pitchfork, but there is nothing fantastic about the food. As a matter of fact, one cannot even accuse Gogol of exaggerating the time spent by his heroes at the table or the amount of food consumed-one has only to read Gogol's own letters describing the gourmet dinners abroad and Selivanova's accounts of the eating habits of the wellborn and the well-shod in nineteenth-century Russia (see note 1). However, master craftsman that Gogol was, he surely would have agreed with E. M. Forster that "Food in fiction is mainly social. It draws characters together, but they seldom require it physiologically, seldom enjoy it, and never digest it unless specifically asked to do so."12 But then, Gogol chose to use gastronomy as a literary device.

Just as Gogol humanizes his devils in The Horrible Vengeance he dehumanizes Ekaterina's father-who in the meantime has become an evil wizard-by making him reject all Cossack fare: specifically, halushky, pork (the favorite meat of the Ukrainians), and vodka. Aside from these instances, Gogol uses gastronomy extensively in Evenings chiefly for its comic effect. He does not do so in St. John's Eve and in The Horrible Vengeance, where

12. E. M. Forster, Aspects of the Novel (New York, 1954), p. 53. 
such an effect would be completely out of keeping with the prevalent tone of these works-the tragic ending in St. John's Eve and the macabre ending in The Horrible Vengeance. Gogol's use of gastronomy for comic effect is not entirely restricted to Evenings. In The Marriage some natural confusion arises because of the character named Fried Eggs. In The Inspector General there is a delectable scene in the beginning of the second act in which we are introduced to Khlestakov, an impecunious scoundrel, who has been mistaken for the bete noire of all mayors and civil servants:

Khlestakov: I'm not going to argue with you, you idiot. (Pours some soup and eats.) You call this soup? You just poured some dishwater into a cup: there's no taste-it just stinks. I don't want this soup, give me another.

WAITER : We'll take it back, sir. The innkeeper said that if you didn't want it, it was all right with him.

KHLESTAKOV (protecting the food with his arms) : There, there, there... leave it alone, you idiot! You're used to behaving like this with others: I, my friend, am quite different. I do not advise you to try the same tricks on me. (Eats.) My God, what soup! (Continues to eat.) I do not think that there is a single human being in this whole wide world who has eaten such soup. Instead of butter, just some kind of feathers float around. (Cuts the chicken.) Ai, ai, ai, what chicken! Give me the roast. There is a little soup left over, Osip, you may have it. (Cuts the roast.) What kind of a roast is this? This is no roast.

WAITER: What is it then?

KHLESTAKOV: The devil alone knows what it is, only it's not a roast! It's just an ax fried to perfection instead of beef. (Eats.) Scoundrels! What scoundrels! Just look at the food they give you! One mouthful is enough to make your jaw ache for a week. (Picks at his teeth.) Bastards! Just like bark splinters-you can't even pull them out! Your teeth will turn black after such repasts. Swindlers! (Wipes his mouth with a napkin.) Is there anything else?

WAITER: No.

KHLESTAKov : Rats! Bastards! Not even some kind of a sauce or a sweet pastry. The good-for-nothings! All they know is how to fleece the travelers. (The waiter and Osip clear the table and carry out the dishes.)

If Pushkin revealed the psychology of his heroes and heroines by means of what they read, Gogol characterized his heroes by what, and especially how, they ate: "Armed with forks the guests stormed the table and began to reveal, so to speak, each his own character and inclination: some applied themselves to caviar, some to salmon, and some to cheese" (5:156-57). In short, to borrow from Feuerbach, for Gogol "Man ist was er isst."

If one discounts the governor of the province in Dead Souls, who set a 
good table, and the chief of police, whose kitchen was an epicure's delight, since "among the citizens of the town, he was a member of the family, and he paid visits to the shops and the merchants' arcades, as if to his own larder" ( $5: 155-56)$, and also Captain Kopeikin, who on a veteran's meager pension preferred elegant dishes (a cutlet with capers, an exotically prepared "poulette" with all kinds of trimmings, and a fantastic soup for which Gogol could find no appropriate name and satirically called "rassupe-delikates"), then during the course of the first part of Dead Souls Chichikov meets five landowners, each of whom satiates his hunger in his own way.

The first landowner Chichikov meets is Manilov, who invites him to dinner. "Be so kind," says Manilov. "You must forgive us if our dinner is not the sort of dinner that is served in the great houses, or in the capitals: we have, according to the Russian custom, shchi [cabbage soup], but it is served in all sincerity" (5:31). Strange! Here is a member of the wealthy landed gentry, a refined Anglophile with impeccable manners and a delicate taste, and yet he satisfies his hunger in such a coarse way. Is it that Manilov, like the hero of Memoirs of a Madman, thirsts for food for his soul, and hence is completely oblivious to the fare set before him? But Manilov has no inner life. Then how can one explain such a glaring contradiction between Manilov's dining at home and his dining in a restaurant, where-as breeding will tell-he displays the delicate palate that is expected of a man from the leisure class:

Manilov was a much more refined gentleman than Sobakevich: he would order a chicken to be boiled at once and would also ask for veal; if they had sheep's liver, he would request sheep's liver too; and he would just taste a little of everything, while Sobakevich would order only one dish, but would eat it all up and even demand a second helping for the same price.

So relates the old woman to Chichikov, who, like Sobakevich, had requested one dish only. But what a dish! A suckling pig, indisputably delightful from his snout to his tail, with horseradish and sour cream. In his eating habits, Chichikov, like the author himself, is not unlike Sobakevich, who, owing to his heredity and class, was not taught to appreciate the fine art of Gallic cooking. Consequently, exotic, esoteric dishes-dishes so dearly prized and cultivated by the most elegant levels of society-are abhorrent to his taste. Yet, as Gogol notes, Sobakevich is not entirely ignorant either ("u etogo guba ne dura"):

"Coat a frog with sugar and I won't put it into my mouth, and I won't touch oysters either: I know what they are like. Do help yourself to some mutton," he went on addressing Chichikov. "It's a saddle of mutton with buckwheat kasha! This is not the sort of fricassee they make in gentlemen's kitchens out of mutton which has been lying about in the market place for four days. That's all been invented by the French and German 
doctors. I'd hang them all for it. It's they who have invented dieting and the starvation cure! Because they've got a weak German constitution, they imagine that they can cope with a Russian stomach! . . They talk of enlightenment, enlightenment, and this enlightenment is just a lot of rubbish. I'd have used another expression, but it would be improper at the table. It's not like this at my house. If I have pork, then put the whole pig on the table, if it's mutton, then fetch the whole sheep, if it's goose, bring in the whole goose! I would rather eat only two dishes, but have as much as my soul desires." Sobakevich confirmed this in practice: he plumped half a saddle of mutton on his plate, ate it all, gnawing it and sucking it to the very last bone. "Yes," thought Chichikov, "this fellow certainly knows what is good."

Complicated gourmet dishes are not for Sobakevich. This giant, whom nature has fashioned like a bear, "works in the food line," as Nabokov correctly notes, "with great slabs and mighty hacks." 13 To dispatch a sturgeon all by himself is merely maintaining his character-being true to himself.

But let us return to Manilov. Even the coarse, crude Sobakevich sets a better table than the refined Manilov. There is only one answer: the Manilovs are not thrifty and are not good at economical housekeeping. If Manilov, having eaten cabbage soup, settles himself into a comfortable armchair and soars in his philosophizing toward the Infinite, the "blockhead" widow, the landowner Korobochka, has her feet firmly planted on the ground. Korobochka's world, like the world of Oblomov's landlady, begins with the garden and ends with the kitchen and the storehouse. Her estate, like the estate in Old-Fashioned Landowners, is a chemical laboratory. And although the bustling and thrifty Korobochka treats Chichikov-the dear old lady was doing this for a purpose-to pickled mushrooms, delicious warm pirozhki, skoro$d u m k i$, shanishki, priagly, and bliny, the specialty and pride of her kitchen, flatcakes with all kinds of accompanying side dishes too numerous to name, and with an unusually fine freshly baked unleavened pirog with eggs, Gogol still does not acquit Korobochka, nor does he make a positive character out of her. ${ }^{14}$ In addition to gaining in movement from so sharp a contrast, Gogol

13. Nabokov, Nikolai Gogol, p. 98.

14. Pirozhki (sing. pirozhok) are yeast-raised rolls or pastry, generally oblong in shape and filled with a number of sweet or savory fillings: meat, fish, cabbage, mushrooms, buckwheat kasha, cottage cheese. Traditionally, pirozhki are served with soup (borshch, broth, or consommé), which in Russia is never served alone. For special occasions short or puff pastry may be substituted for the yeast-raised dough. In his translation of Dead Souls (Baltimore, 1961), David Magarshack defines skorodumki (sing. skorodumka) as "fried eggs" (p. 66); a Soviet edition of Gogol's works, Izbrannye proizvedeniia (Moscow, 1946), defines skorodumki as pirozhki (p. 358). Dal's definition for skorodumki (Tolkovyi slovar", 4:205) is: "Veshchi, delo . . . skorospeloe, vdrug, naskoro zadumannoe i sdelannoe. Skorodumka, vost. iaichnitsa vypusknaia ili glazun'ia." It seems to me that within the context of Gogol's Dead Souls (skorodumki is the second 
seems to be adding: Yes, Korobochka's world is pitifully narrow and circumscribed, but is Manilov so far ahead of her?

The novel also brings out the contrast between Korobochka and the landowner Nozdrev. But from the standpoint of economic housekeeping, Korobochka can also be compared with the landowner Pliushkin, who, upon learning that he would profit from Chichikov's unorthodox transaction, offered him some dried-up kalach, baked by his daughter vo vremia ono, and some "likerchik" from which the miser had painstakingly removed all kinds of worms, insects, and dirt. ${ }^{15}$ Chichikov, always ready to sit down to a meal, abstained from such epicurean delights, pleading-much to the relief of Pliushkin - that he had already dined. Under the pretext of checking whether his help ate well, the miser gorged himself daily in the kitchen on cabbage soup and kasha. ${ }^{16}$ Aside from Manilov's and Pliushkin's distinctive eating habits, Gogol correctly ascribes cabbage soup and kasha as the typical fare, the staple cliet, of the peasants. And whenever one of his heroes becomes class conscious (in Gogol's Russia they all invariably do)-for example, when Poprishchin in Memoirs of a Madman derides the merchant class-Gogol notes that the merchants smell of "cabbage." In Nevsky Prospect there is yet another reference to the "Russian beards" (merchants) and the smell of cabbage that lingers over them. In this same story the narrator also sympathizes with all those who have been blessed with a mouth the size of the arch of the staff headquarters in St. Petersburg - a gargantuan size indeed if one remembers that this celebrated edifice has the longest curved façade in the world and the arch itself is several stories high-yet whose misfortune forces them to satisfy their extraordinary appetites with a frugal "German dinner of potatoes" $(3: 42) .{ }^{17}$ Gogol was not the only one to associate Germans with potatoes: Lermontov did the same in his long erotic poem Sashka, and Goncharov followed suit in Oblomov. It is interesting that both Gogol and Goncharov chose to characterize the financial well-being of a household by the amount of coffee consumed on a given day. In The Nose the barber must choose between a

item in a list of buns and pancakes) pirozhki would be the more probable definition for skorodumki.

Shanishki are a variety of a vatrushka, which is an open pastry with a cheese center. Priagly (olad'i) are thick pancakes, generally made from potatoes. Bliny are very small pancakes, about four inches in diameter, made of raised paste of buckwheat flour. Bliny should be served hot with melted butter, cold thick sour cream, caviar, slices of smoked salmon, and finely chopped herring.

15. Kalach is a braided ring-shaped bread, somewhat richer than ordinary bread.

16. Any baked or cooked (like porridge) cereal is called kasha. It may be made of buckwheat groats, rice, barley, wheat, millet, or corn meal. All varieties of kasha are served as a substitute for potatoes or as a basic dish to accompany a protein food. Buckwheat kasha is the national favorite.

17. This is a second association of potatoes with Germans. The first one occurred when Gogol described Schiller and his way of life (p. 39). 
slice of fresh bread and a cup of coffee-he is too poor to have both. And the number of cups of coffee consumed every day proved to be a reliable measure for the financial ups and downs of Oblomov's landlady. Hence, in Dead Souls and elsewhere Gogol not only uses gastronomy to characterize his "anti-heroes" but also as a realistic detail (what one habitually eats) even to define their class and national origin in the socially structured Imperial Russia.

"Katai-valiai" ("we shall make it all out later") is Nozdrev's motto, applicable to every sphere of his tempestuous life, including the table to which, as expected, he paid no attention whatsoever, although he "was very particular about wines" $(5: 78-79)$. One is not surprised to find in his chapter a catalogue scene, a whole page dedicated to an enumeration of wines, which were forced upon the guests in that very same helter-skelter order so characteristic of Nozdrev and his cook-a mere extension of Nozdrev himself. Nozdrev's antithesis is to be found in the second, the unfinished part of Dead Souls in that rotund figure of Peter Petrovich Petukh, for whom dinner is the most crucial issue in life. "Have you dined?" he greets stranger and friend alike. And if he should receive a positive answer: "What, have you come to make fun of me?... Of what use are you to me after dinner?" (5:314). Like his famous kulebiaka, he is stuffed every day with all kinds of rare and caloric delicacies. Peter Petrovich Petukh is the culmination of all the gourmets, gourmands, and gluttons who form a marvelous gallery in the literary works of Gogol, beginning with Evenings and ending with Dead Souls. Petukh's instructions to his chef on how to prepare a kulebiaka-an indisputably delicious dish which fortunately does not suffer because of its drab name-are an ode to an epicure: "Even the dead will grow an appetite," remarks the pleasantly stuffed and drowsy Chichikov, trying in vain to fall asleep $(5: 320)$ :

"Make a four-cornered fish pie," he was saying, smacking his lips and sucking in his breath. "In one corner put a sturgeon's cheeks and dried spinal cord, in another put buckwheat porridge, little mushrooms, onions, soft roes, and brains and something else-well-you know, something nice ... And see that the crust on one side is well browned and a little less done on the other. And make sure the under part is baked to a turn, so that it's all soaked in juice, so well done that the whole of it, you see, is-I mean, I don't want it to crumble but melt in the mouth like snow, so that one shouldn't even feel it-feel it melting." As he said this Petukh smacked and sucked his lips.

"Damn him, damn him!" thought Chichikov. "He won't let me sleep," and he buried his head in the blanket, so as not to hear anything. But even through the blanket he could hear Petukh saying:

"And as a garnish for the sturgeon, cut a beetroot into little stars and put in some smelts and mushrooms and, you know, a turnip and 
carrots and kidney beans and something else-you understand, something nice, so that there will be a lot of garnishing. And don't forget to put some ice in the pig's stomach so that it will swell up properly." Petukh was ordering many more dishes. Chichikov heard him saying repeatedly: "And see that it's well roasted and baked, and see that it's well basted." Chichikov fell asleep over some turkey. ${ }^{18}$

Can one find a similar minute description of a gourmet dish in all of Russian classical literature-in Pushkin, for example, or in Lermontov, Turgenev, Goncharov, Tolstoy, Dostoevsky, or even in Chekhov's amusing story "The Siren," where Chekhov, like Gogol, uses food to degrade and trivialize his characters? True, one remembers the roast beef in Eugene Onegin, the oysters which as a leitmotiv follow Dolly's husband in Anna Karenina, the gooseberries in Chekhov, and, more recently, those famous cream pastries that wrought the hero's undoing in Zoshchenko's "The Aristocrat." But nowhere do we find, as in Gogol, such devotion to fine food. Tolstoy had infinite opportunities in War and Peace to describe the gourmet dinners that last for pages and pages, yet he confined his description to the glitter of the crystal and the clinking of the silverware, and placed all emphasis on social discourse. It is unlikely that such descriptions will be found in Soviet literature-other themes, other times, and other temperaments. In Gogol's literature, such as Memoirs of a Madman, even dogs are endowed with an exquisite taste and dream of dinners worthy of their masters.

In Dead Souls gastronomy not only helps to reveal the psychology and the idiosyncrasies of this or that landowner, but as a vehicle of satire, a symbol of poshlost', it also helps to unite these outwardly heterogeneous, yet spiritually identical, characters. From the standpoint of composition, Gogol chose no easy task when he decided to present various types of Russian landowners, impoverished in spirit, devoid of all higher passions and goals, yet firmly convinced of their own value and their rights. It was indeed impossible to unite this group of poshliaki (vulgarians) by a love motif: the buying and the selling of peasants was the only possible solution, and it united the landowners from an economic point of view. The thriftiness (khosiaistvennost') of Sobakevich, Korobochka, and Petukh, and the unthriftiness (nekhosiaistvennost') of Manilov, Nozdrev, and Pliushkin, best expressed itself in their ability to set a good table (khlebosol'stvo). But the ability to set a good table is a twoedged sword in Gogol's hands. When it becomes an end in itself, a goal in life, as in the case of the landowner Petukh, whose home became a temple of gastronomy, then it justly and unmercifully falls on the head of the guilty.

18. Magarshack's translation of Gogol's Dead Souls, p. 311. In his recollections about Gogol, L. I. Arnoldi mentions that Gogol, "just like Petukh . . . was capable of conversing with the chef for a whole hour about some kulebiaka." $N$. V. Gogol'v vospominaniiakh sovremennikov $i$ perepiske, ed. V. V. Kallash (Moscow, 1909), p. 89. 
Thus, the ability to set a good table is an important criterion by which Gogol judges his landowners, and is basically perhaps more important than the comparison of the landowners on an intellectual plane and a further comparison of their reaction to Chichikov's "transaction," since it cuts to the very core of the theme that Gogol had chosen for his masterpiece. If Gogol had set himself the task of unmasking a world of human beings devoid of an inner life, higher goals, passions, and aspirations, he could have fulfilled this arduous task only by depicting them in the physiology of their existence. What did Neanderthal man need to preserve him from extinction? Food, clothing, a roof over his head, and a woman. What do the two old-fashioned landowners, Shponka, Chichikov, Manilov, Sobakevich, Ivan Ivanovich, and Ivan Nikiforovich need? Food, clothing, a roof over their heads, and a babenka. It would be impossible to extract gastronomy from Dead Souls without destroying its meaning, for here it is primarily a symbol of poshlost', an effective device for degrading and trivializing characters. Without gastronomy there would be no wonderful tale of the two good-natured Old-Fashioned Landowners. However, gastronomy here serves basically an entirely different purpose: it is Pulkheriia Ivanovna's way of expressing her deep and abiding love (more about that later) for Afanasii Ivanovich. It would indeed be a mistake to interpret gastronomy here-as in Dead Souls-as a vehicle of satire, just as such a conclusion would be erroneous in Thomas Mann's The Magic Mountain, although elements of satire that have little to do with gastronomy are definitely present in these two dissimilar works of art.

On the very first pages of Dead Souls Gogol divides his heroes into the thin and the portly: "Alas, the portly ones know far better than the thin ones how to arrange their affairs in this world" ( $5: 15)$. Marking well, Gippius develops this idea further: "In Gogol's world of poshlost' one can discern static poshlost', that is absence of all movement, and the dynamic poshlost' of this very movement as if these were two spheres-a lower sphere, and a somewhat -but only comparatively speaking - higher sphere."19 Defining "dynamic poshlost"' Gippius states:

Everything that is a requisite trapping of the lower sphere can, apparently, become an object of a passion, an object of movement. Satisfaction with food, clothing, hearth, a woman, ranks, and moneys can transform itself into a passion for gastronomy, dandyism, elementary eroticism, and a scramble after ranks and money. These are not passions that could have created real dynamics and could have developed in a tragedy. These are passions that create a false illusion of dynamics, and here lies the essence of Gogol's humor. ${ }^{20}$

19. Vasilii Gippius, Gogol' (Leningrad, 1924), reprinted by Brown University Press, Reprint Series, no. 3 (Providence, 1963), p. 156.

20. Ibid., p. 159. 
Better still, here lies the essence of Gogol's satire. Hence, on one hand, as in Old-Fashioned Landowners, How Ivan Ivanovich Quarreled with Ivan Nikiforovich, and Dead Souls, Gogol portrays the successful and portly landowners, civil servants, and government officials who wallow in self-contentment, for in their own estimation they have attained an ideal existence. But according to Gogol they are as far removed from an ideal life as the beauty that the painter Piskarev found on the illusive Nevsky Prospect was from Perugino's Bianca. On the other hand, in the Petersburg stories Gogol depicts all the thin ones who are trying to attain the blessed state of the portly. Even Akakii Akakievich Bashmachkin is included by Gippius in the world of the "dynamic poshlost'," as he dreams of a new overcoat, which he finally possesses only too briefly. The heroes of the Petersburg stories are all in pursuit of something, be it an ideal, as in the case of Piskarev, gold and fame for the artist Chartkov, an easy feminine conquest for Pirogov, or a more prestigious rank and office for Major Kovalev. Even Akakii Akakievich is superficially possessed with a zador - a passion to be well-dressed. Since all the heroes in the Petersburg stories are in pursuit of a life epitomized by the portly, there is no room for gastronomy in these stories. Oh, yes! Pirogov may have eaten two pirozhki, as a substitute for an erotic experience, and definitely as a consolation prize for the sound thrashing administered to him by the two lowly German artisans, but Major Kovalev, in search of his nose and whatever that facial appendage may symbolize, enters and exits from a pastry shop without eating a thing. As a matter of fact, it is the absence of gastronomy that is most apparent in the Petersburg stories. Then, too, lack of humor-that is, mirth and merriment for its own sake (as in Evenings) and not as a weapon for derision-made it impossible for Gogol to insert his highly successful comic scenes centered around gastronomy into the Petersburg stories. And by concentrating on the psychology of Bashmachkin, Kovalev, Piskarev, Pirogov, and Poprishchin, Gogol precluded bouts in the kitchen and at the table.

Aside from Gogol's repetitive use of "charactonyms" to reveal the essence of a character or place, among which names that have to do with gastronomy (Piskarev, Pirogov, and landowners Tovstoguby, the old woman Pereperchikha, the Cossack Korzh) occupy a prominent place, there is still another aspect that emerges from Gogol's comparison of human beings with something edible. Very often the author speaks in one breath of food and women. In Homegoing from the Theater After a New Comedy (Teatral'nyi raz'ezd posle predstavleniia novoi komedii) "two very proper people" dissect the new play :

FIRST COMME IL FAUT [i.e., "very proper gentleman"] : . . Do you know the name of this young actress?

SECOND COMME IL FAUT: No, but not bad at all. 
FIRST COMME IL FAUT: Yes, not bad; but still, there's something missing.

Oh, yes, I recommend a new restaurant: yesterday we were served green peas (kisses the tips of his fingers)-delicious!

From a "green" actress the conversation turns to green peas, and the promising actress, as far as Gogol's two theatergoers are concerned, is forgotten. Khlestakov in The Inspector General writes to his friend Triapichkin:

I am staying now at the mayor's, and am having the time of my life, as I run wild after his wife and daughter. Only I haven't quite decided with which to begin: probably, I think, first with the mother, for she seems to be ready and willing tight now. Do you remember what tough times you and I used to have, eating as catch can, and how a baker once grabbed me by the collar because I had eaten some pirozhki and charged them to the account of His Majesty the King of England?

In the play Anna Andreevna is casually linked with sour pickles and, indirectly, with Khlestakov-the note that her husband wrote informing her of Khlestakov's arrival was written on one of Khlestakov's old bills. Significantly, the pseudo inspector general pursues her first and not her marriageable daughter. The young thing that captures Chichikov's fancy in Dead Souls is repeatedly said to have an egglike face: the freshness of the egg, underlined by Gogol, is symbolic of her innocence, youth, and vulnerability. In the eyes of Chichikov the governor's daughter is also "a very tasty piece" (ochen' lakomyi kusochek) (5:97); one must remember that the sugar cubes, which symbolize women in that famous passage about the frockcoat flies, are also referred to as lakomye kuski (5:14-15). Prelakomyi kusok and "peach" are words that Lermontov uses to describe a sexually attractive woman in his highly erotic poem Sashka: persiki is used first to designate the woman's breasts, but then the simile is extended into a metaphor and the courtesan herself becomes a persik. ${ }^{21}$ There are other associations of women with food in Dead Souls and elsewhere. In addition to their symbolism, these associations, unusual as they are at times, are frequently used as a means of charac. terization: the sexually attractive peasant girls, for example, the belogrudye and stroinye devki in Dead Souls, have eyes like turnips (peasants - turnips) $(5: 292)$; the exotic beauty to be painted by Piskarev for the Persian merchant in exchange for opium must have eyes like olives (Persians, exotic beauty exotic, imported food) $(3: 26)$; and the old peasant woman-she is also a witch-in St. John's Eve has a face like a baked apple (Ukraine - cherry, apple orchards) (1:50). Perhaps the best association, in the Freudian sense, of women with food occurs in The Nose when Gogol describes the doctor to whom Pirogov turned in his dilemma: "The doctor was a man who stood out 400.

21. M. Iu. Lermontov, Sobranie sochinenii, 4 vols. (Moscow, 1958-59), 2:405, 427, 
in a crowd ... he had a fresh, healthy wife, ate fresh apples in the morning [even the adjective svezhii is the same] and kept his mouth immaculately clean, rinsing it every morning for three quarters of an hour, and polishing his teeth with five different kinds of brushes" $(3: 63)$. The apple in Western literary tradition has long been a symbol of sexual love as distinct from marital love:

On her way, she moved to the fireplace, bent down, took the last heavy log lying in front of it in her shining bare arms, and flung it into the embers. And then she turned, her face sparkling with flames and joy; in passing, she snatched up an apple from the table, and was again in my arms, her limbs still bathed in the fresh heat of the fire, then dissolving, as it were, in the yet fierier flames which pulsed through them from within. Clasping me with her right hand, she bit into the cool fruit in her left, then held it to my mouth, offering the fruit, offering her face. The last $\log$ in the fireplace flamed higher than all the rest. With a shower of sparks it sucked in the flames, then hurled them up again in a furious blaze, and the firelight broke over us like a wave dashing against the wall, flinging our shadowed embrace up and down upon it. The great log crackled, feeding from its heart fresh flames which danced upward, dispelling the darkness with sheaves and fountains of glowing red..2

And this business of eating either precedes sex (as in Paradise Lost and Tom Jones) or is synonymous with it (as in a number of Restoration plays that treat sexual license). ${ }^{23}$ Considered in this light, the doctor's preoccupation with "fresh apples" so early in the morning receives quite a different interpretation. And hence his attitude toward women contrasts dramatically with that of the "two very proper people" and that of Khlestakov, who, in my opinion, flees the town not only from fear of discovery that he is not the inspector general after all, but also-quite unconsciously-from the two women with whom he unwittingly has become involved and whom he has no intention of marrying. His sentiments, expressed in that famous remark which has since become a krylatoe slovo, reveal that he is primarily interested in food and not in women.

Association of food with sex is not entirely unknown in Russian literature, although no classical Russian author is as persistent in this tendency or devotes as much space to this psychological reality as Gogol. The best example

22. Hugo von Hofmannsthal, Selected Prose, trans. Mary Hottinger and Tania and James Stern (New York, 1952), p. 312.

23. In Thomas Otway's Don Carlos, Prince of Spain, the Duchess of Eboli (in love with the prince) invites Don Carlos to "a feast," that is, herself. In George Etherege's play "The Man of Mode, or, Sir Fopling Flutter" Belinda is consumed by a strange desire to eat nectarines early in the morning. When questioned, she confesses to her fault, but it is understood by all present that the conversation is not in fact about the nectarines which she has just eaten. 
by far occurs in Oblomov, where Goncharov had as many opportunities as Gogol to use food either for its aesthetic value or as a vehicle of satire. But until Oblomov moves into his new flat on the Vyborg side he is oblivious to the fare set before him. Consequently, descriptions of food are almost nonexistent. But after he meets the buxom young, attractive widow (a younger cousin of Korobochka), who is also his landlady, he suddenly becomes foodconscious. There can be little doubt that Goncharov chose here to associate food with sex. Time and time again he is sure to underline that this delicious cup of coffee or that tantalizing chicken-and-mushroom pie was served, not by a woman, but by a naked arm with a charming elbow-an arm which Oblomov found as sexually exciting as his landlady's plump neck and her high bosom. ${ }^{24}$ Another interesting association of food with women and sex occurs in Korolenko's short story "Marusia's Domicile": "One of my acquaintances, who considered himself an expert on women, once made a funny remark, that one can discover whom a peasant woman loves by observing with whom she eats more willingly." ${ }^{25}$

Gogol's heroes can also gormandize first and then turn their thoughts upon a woman. Let us observe what happens. Akakii Akakievich, having feasted for the first time on a superb supper of vinigret, cold veal, pâté, pirozhki from a pastry shop, and champagne (two glasses), instinctively betakes himself after a woman "who passed him like lightning" $(3: 147){ }^{26}$ Immediately, however, he has second thoughts-and nothing happens. And that "very important person" who literally scared Akakii Akakievich to death, after drinking some champagne forgets his conscience and turns his thoughts, as well as his steps, to his German "Liebchen"-but at the last minute is prevented by Bashmachkin's "ghost" from reaching his destination. It seemed as though Nemesis herself had come to avenge the loss of Bashmachkin's coat-wife. If Akakii Akakievich lost his love, neither was the "very important person" destined to see his Carolina. And what about Captain Kopeikin, who having dined well on a cutlet with capers, a bottle of wine, and a fantastically prepared fatted fowl, is suddenly inspired to hobble along on his wooden leg after an Englishwoman who glided past him like a swan. However, once more, nothing happens. Khoma Brut in $V i i$, after having searched all the hiding places of the seminary for food, woos a young widow, and "there is no telling what was laid on the table before him in the little clay hut in the middle of a cherry orchard" (2:165). One hopes that the young woman was justly

24. There are a number of associations, but one or two will be sufficient: "'She's only a clerk's widow, but she has elbows good enough for a countess, and with dimples too!' Oblomov thought" (p. 312); "A bare arm, hardly covered with the shawl he had already seen, was thrust through the door of the side room holding a plate with a huge piece of steaming hot pie" (p. 313). Ivan Goncharov, Oblomov, trans. Natalie Duddington (New York, 1960).

25. V. G. Korolenko, Povesti i rasskazy (Moscow, 1960), 2: 349.

26. Vinigret is Russian salad that invariably contains either meat, game, or fowl. 
rewarded for her hospitality, but with Gogol's heroes it would be an exception to the rule.

From the examples cited, save for the doctor and the major in The Nose, it seems that contrary to literary tradition, especially Western literary tradition, where the act of eating symbolizes or serves as a prelude to the physical act that invariably follows, Gogol in his fiction not only tries to reverse the order, in which case food becomes a substitute, but is also bent on separating the two. The best example of this occurs in The Fair at Sorochintsy. As I have already indicated, gastronomy is used here consciously mainly for comic effect, but unconsciously Gogol is presenting his hero with a psychological problem-a choice between food and a woman. One might add here that women never fare well in Gogol's fiction: there is not a single real, flesh-and-blood heroine in his gallery of feminine portraits. That is not to say, however, that Gogol failed to see a feminine ideal. On a number of occasions-Ulinka in Dead Souls, Annunciata in Rome-the author tried to realize his ideal of feminine beauty, but one must admit that his ideal women, unlike his termagants, are unconvincing and fail to come to life. Seldom indeed, therefore, do we find in Gogol a positive portrait of a woman. In vain one looks for a living and breathing Tatiana Larina or a Natasha Rostova. But examples of "a product of Hades" (the first words of Gogol's sketch entitled "Woman") we encounter frequently-Khavronia Nikiforovna in The Fair at Sorochintsy being the first, but not the last, of them :27

"Here is an offering for you, Afanasii Ivanovich!"-said Khavronia to the bashful priest's son, setting some bowls on the table and coyly fastening the buttons on her blouse, as if they had not been undone on purpose. "Varenychky, halushechky pshenychnye, pampushechky, tovchenychky."28

"I bet they have been made by the cleverest hands of any daughter of Eve!" said the priest's son, setting to work on the tovchenychky and with the other hand drawing the varenyky toward him. "Though indeed, Khavronia Nikiforovna, my heart thirsts for a dainty from you sweeter than any pampushechky and halushechky!"

"I don't really know what other dainty you want, Afanasii Ivanovich!" answered the buxom beauty, pretending not to understand.

"Your love, of course, incomparable Khavronia Nikiforovna!" whispered the priest's son, holding a varenyk in one hand, and encircling her ample waist with the other.

"Goodness knows what you are talking about, Afanasii Ivanovich!" said Khivria, bashfully lowering her eyes.

"Why, I shouldn't wonder, you'll try to kiss me next."

27. N. V. Gogol, Polnoe sobranie sochinenii, 10 vols. (Berlin, 1922), 7:236.

28. Varenychky are curd dumplings, halushechky pshenychnye are wheaten dumplings, pampushechky are buns, and tovchenychky are fish or meat buns (or dumplings). 
"As for that, I must tell you," the young man went on, "when I was still in the seminary ... I remember as though it were today -"

Talk, talk, talk, and Khavronia's romantic notions in spite of her formidable artillery will-unlike those of Mrs. Waters in Tom Jones-bear no fruit, for among other things popovich will quickly discern that the she-devil will always be there, but a varenyk can get cold. Consequently, he is surprised not with Khivria in his arms but with a varenyk in his mouth. And that, judging from Gogol's life, would also have been the author's choice. It is no secret that Gogol did not have a single meaningful love affair with a woman, and that his relations with women on the physical plane left much to be desired. According to Carl Proffer, "Gogol's sex life is filled with booby-traps."'29 A number of critics have tried to explain Gogol's cool attitude toward women as being the result of an Oedipus complex, and they have even alluded to homosexual tendencies. If one accepts these theories, then Gogol has unconsciously endowed most of his heroes with his own fears and anxieties. If one does not accept these theories, then one faces the problem of finding an alternate solution to explain a definite pattern of attitudes toward women that emerges from Gogol's fiction. From The Fair at Sorochintsy to Dead Souls Gogol's heroes not only consider women to be an inaccessible ideal of beauty, poetry, and perfection, but also devalue them sexually, exhibit a morbid fear of them, and balk at getting married. Of course, as Gerhard Gesemann states in his psychoanalytical study of Gogol, it is not always safe to assume that the main traits of an artist's nature will find representation and correspondence in the artist's works. ${ }^{30}$ However, Gogol, in Gesemann's opinion, is almost a "classical example for the general rule that the most significant character traits for an artist will invariably find their parallels in the most significant traits of his art." The woman then-the unattainable tormentor-is an object of both love and hate to Gogol, and this personal ambivalence toward women, stemming from an Oedipal fixation, finds consistent reflection in his art.

Since the object of the author's desires was forbidden and unattainable, the frustration of Gogol's libidinal motives must necessarily have been accompanied by feelings of guilt, anxiety, and fear of punishment. As Hugh McLean correctly surmises, Gogol had to find a solution for his anxiety. ${ }^{31} \mathrm{He}$ found it, in my opinion, not in a regression to a pre-Oedipal stage, but in sublimation.

29. Letters of Nikolai Gogol, selected, edited, and translated by Carl R. Proffer (Ann Arbor, 1967), p. 213.

30. Gerhard Gesemann, "Grundlagen einer Charakterologie Gogols," in Jahrbuch der Charakterologie (Berlin), 1 (1924): 49-88; quotation, p. 54.

31. Hugh McLean, "Grogol's Retreat from Love: Toward an Interpretation of Mirgorod," American Contributions to the Fourth International Congress of Slavicists (The Hague, 1958), pp. 225-44. 
As Freud states: "In dreams a table is very often found to represent a bed. 'Bed and board' together mean marriage, so that one easily stands for the other."32 And this is precisely the solution that Gogol chose and why we find in his works as nowhere else in Russian literature repetitive association of food with sex and, contrary to literary tradition, an unconscious desire to separate the two-all for a good reason: when Gogol sublimated his desire for his mother by turning to food, subconsciously his deep moral sense could not help but be outraged by such a satisfaction of a forbidden desire. By necessity this led to an ambivalence toward food, guilt feelings about it, and consequently a chronic state of anxiety for punishment. And what better means of punishment could Gogol have chosen for himself than to have his stomach make eating impossible. The author's complaints of intestinal disorders and protestations that the doctors had found his stomach to be literally upside down could fill a small volume if they were ever extracted from his voluminous correspondence. As early as 1832 (twenty years before his death) Gogol confided to the unbelieving Aksakov that "the cause of his illness lay in the stomach." 33

In the end Gogol, like his heroine Pulkheriia Ivanovna, met his need for punishment by starving himself to death. Outwardly Gogol attributed his motives to a desire for self-purification. In his well-known and often quoted study of Gogol's The Overcoat Tschižewskij concludes that Gogol attached philosophical and religious meaning to human passions (zadory) ${ }^{\mathbf{3 4}}$ The devil -and he is ever present in Gogol's art-lies perennially in wait to trip Man and to divert his striving toward God; he achieves this purpose by enticing Man with little insignificant worldly things, such as Akakii Akakievich's overcoat. It is no coincidence on the author's part, continues the critic, that the tailor Petrovich is either called a devil or is associated with the nechistyi. One can find a similar association of food with the devil in the examples already cited in the body of this paper: there is that devil-chef in Christmas Eve; in the Lost Epistle the devils set the table for the unsuspecting Zaporozhets; and Gogol's most talented cooks, if not literally witches, are at least their first cousins. Therefore, in his moral transformation, Gogol, like the monk in The Portrait, had to abstain from food. In another study, while discussing Gogol's spiritual development, Tschižewskij mentions that there were widespread rumors in Russia in the 1830 s about the coming of the Antichrist. In the first version of The Portrait Gogol speaks about the Antichrist's coming, but in

32. Sigmund Freud, A General Introduction to Psychoanalysis, trans. Joan Riviere (New York, 1958), p. 273.

33. S. T. Aksakov, Istoriia moego znakomstva s Gogolem, ed. E. P. Naselenko and E. A. Smirnova (Moscow, 1960), p. 11.

34. D. Cyževskyj, "Zur Komposition von Gogol's 'Mantel," Zeitschrift für slavische Philologie, 14 (1937): 63-94, see esp. pp. 78-92. 
1840 he deleted these lines. ${ }^{35}$ As was to be expected, speculations arose as to the guise in which the Evil One would make his appearance. A popular belief -one with which Gogol surely must have been familiar-prophesied that the Antichrist would appear as a chef-extraordinary. Years later Gleb Uspensky gave embodiment to this popular legend in his sketch "Without Will."

In conclusion, it is not within my province to prove or disprove the theory that Gogol suffered from an Oedipus mother fixation, or, for that matter, from latent homosexuality. This remains a task for a trained and competent psychologist who is also thoroughly familiar with Gogol's life and art. However, the consistent sexual devaluation of women by Gogol's heroes, and their preoccupation with food as a substitute, seems to me to be in agreement with these theories. Seen in this new light, Manilov's disinterest in food at home can be explained perhaps not only from an economic standpoint but also by his wife's "prolonged kisses" ( $5: 27) .{ }^{36}$ Similarly, the hero in The Carriage, being quite satisfied with his comely wife, forgets, yes forgets-an unheard of thing for Gogol's heroes-even to order the dinner (quite a ceremony in itself) to which he had invited several visiting officers. To be sure, his actions are psychologically motivated: he was stone drunk when he collapsed beside his lovely tidbit, but upon awakening his first reaction was to reach for a kiss and not to summon his cook. These few maverick heroes, in my opinion, represent in Gogol's fiction the sexually normal male, who has a satisfactory personal life and hence places little emphasis on food. The others-who for some reason or other are incapable of personal happiness-stake all at the table. The link between these two kinds of heroes is the couple in Old-Fashioned Landowners, whose once passionate love-years ago Afanasii Ivanovich abducted Pulkheriia Ivanovna-expresses itself in their senility through Pulkheriia Ivanovna's unique culinary language. ${ }^{37}$ Almost in a class by himself is Major Kovalev, 126-58.

35. D. Chizhevsky, "Neizvestnyi Gogol'," Novyi Zhurnal (New York), 27 (1951):

36. With especial vehemence Gogol twice underlines these "prolonged kisses."

37. I do not quite agree with McLean's interpretation of Old-Fashioned Landowners: "The fact that they have the same patronymic may be a suggestion that their real relationship is that of brother and sister, safely pre-genital and Platonic" (McLean, "Gogol's Retreat from Love," p. 239). On the contrary, their love-in its initial stage-must have been very passionate: one must remember that Ivan Ivanovich abducted his beloved. Gogol's own views on love in marriage, expressed in a letter to A. S. Danilevsky (March 30, 1832), seem to support this: "Beautiful, fiery, exhausting, and inexplicable is love before marriage; but he who has loved before marriage has displayed only one burst, one effort to love. This love is not complete; it is only a beginning, momentary, but it is a strong and fierce enthusiasm which shakes the organism of a man for a long time. But the second part, or better, the book itself . . . is calm, an entire sea of quiet pleasures which open up more and more each day; and you are amazed by them with all the more pleasure because they seemed absolutely insignificant and ordinary" (Proffer, Letters of Nikolai Gogol, p. 41). When we meet this lovable pair, they are oldstarichki Gogol calls them page after page-and, as is to be expected, are no longer 
the sole male character in Gogol's fiction who in spite of his basic fear of women nevertheless is obsessed with them. Major Kovalev's inner conflict, brought about by Madame Podtochin's-how apt is the name-direct and persistent pressure on him to marry her daughter, is resolved neither by a fenestral flight nor by turning to food as a substitute. Instead, Major Kovalev becomes temporarily impotent. And without his nose, which, as Peter Spycher points out in his delightful article, is a symbol of the major's manhood, Kovalev cannot even contemplate food. He enters a pastry shop and does the unheard of in Gogol-he exits without eating a thing $!^{38}$ Like Oscar Wilde's Salome, and unlike the majority of Gogol's "heroes," Kovalev's hunger will be appeased by "neither wine nor apples." ${ }^{39}$ In Gogol, as we already know, apples assume the form of a pirozhok. But after the recovery of his nose, even before he is fully inside the pastry shop, Major Kovalev overrides Gogol, joins the literary tradition, and shouts: "Boy, a cup of chocolate" (3:69).

sexually active. For some time now they have been sublimating their libidinal desire for each other by turning to food-Pulkheriia Ivanovna's culinary language is really an expression of her love for her husband. Since Gogol was never really successful in portraying sexual love, perhaps this is one of the underlying reasons why he chose to portray his old-fashioned landowners in their senility and why eventually he gets rid of Pulkheriia Ivanovna for no apparent reason at all. She had to meet her punishment for associating food with sex.

38. Peter C. Spycher, "N. V. Gogol's 'The Nose': A Satirical Comic Fantasy Born of an Impotence Complex," Slavic and East European Journal, 7, no. 4 (1963) : 361-74. In his convincing article Spycher fails, however, to mention why Kovalev's nose was found baked in a loaf of bread and not, let us say, in some empty cupboard or in the barber's shaving cream. However, if one accepts Gogol's association of food with sex, then the major's nose could not have been found anywhere else but in a loaf of bread.

39. Oscar Wilde, Salome, trans. from the French by Lord Alfred Douglas (New York, 1967), p. 65: "I saw thee, and I loved thee. Oh, how I loved thee! I love thee yet, Iokanaan. I love only thee. . . I I am athirst for thy beauty; I am hungry for thy body; and neither wine nor apples can appease my desire." 